Vol. 45, N. 1 : pp. 1 - 5, March, 2002

ISSN 1516-8913 Printed in Brazil

\title{
Cowpea Vicilins: Fractionation of Urea Denatured Sub- Units and Effects on Callosobruchus maculatus F. (Coleoptera: Bruchidae) Development
}

\author{
Antônio Chagas Mota ${ }^{1,2}$; Kátia Valevski Sales Fernandes ${ }^{3}$; Maurício Pereira Sales ${ }^{4}$; Victor \\ Martin Quintana Flores ${ }^{5}$ and José Xavier-Filho ${ }^{3^{*}}$ \\ ${ }^{1}$ Departamento de Bioquímica e Biologia Molecular, Universidade Federal do Ceará, 60001-970 Fortaleza, Ceará, \\ Brazil; ${ }^{2}$ Universidade Estadual Vale do Acaraú, 62040-370, Sobral, Ceará, Brazil; ${ }^{3}$ Laboratório de Química e \\ Função de Proteínas e Peptídeos, Centro de Biociências e Biotecnologia, Universidade Estadual do Norte \\ Fluminense, 28015-620 Campos dos Goytacazes, Rio de Janeiro, Brazil; ${ }^{4}$ Departamento de Bioquímica, \\ Universidade Federal do Rio Grande do Norte, 59072-970 Natal, Rio Grande do Norte, Brazil; ${ }^{5}$ Laboratório de \\ Biotecnologia, Centro de Biociências e Biotecnologia, Universidade Estadual do Norte Fluminense, 28015-620 \\ Campos dos Goytacazes, Rio de Janeiro, Brazil
}

\begin{abstract}
Vicilins (7S storage globulins) isolated from cowpea (Vigna unguiculata L.) seeds which were susceptible (S) and resistant $(R)$ to the cowpea weevil (Callosobruchus maculatus F., Coleoptera: Bruchidae) were denatured by urea and fractionated by ion-exchange chromatography. Isolated fractions were incorporated in artificial seeds for assessment of their toxicity to $C$. maculatus. The most acidic fractions of both susceptible (CE-31 cultivar) and resistant (IT81D-1045 line) seeds were shown to affect development and survival of the bruchid. Results indicated that vicilin polypeptides of toxic nature were expressed in both types of storage globulins although at different levels.
\end{abstract}

Key words: Vicilins, 7S storage globulins, urea denaturation, cowpea, Vigna unguiculata, Callosobruchus maculatus, development

\section{INTRODUCTION}

Cowpea (Vigna unguiculata L.) seeds are widely utilized by low income populations in tropical and sub-tropical regions (Singh and Rachie, 1985). Subsistence farmers, which are most responsible for the cowpea culture, are heavily at loss due to low yields that are mostly caused by diseases and insect attack (Jackai and Daoust, 1986). When in storage, the cowpea is heavily damaged by the cowpea weevil (Callosobruchus maculatus F.,
Coleoptera: Bruchidae). Control of this pest is usually done through the utilization of chemical insecticides that are costly and environmentally damaging (Jackai and Daoust, 1986; Egwuatu, 1987). Some years ago a source of varietal resistance was found in Nigeria and this was utilized for incorporation of the trait in commercial lines (Singh and Singh, 1992). It is known that the resistance of these seeds towards $C$. maculatus is due to the presence of variant vicilins ( $7 \mathrm{~S}$ storage globulins) (Xavier-Filho et al., 1989). These

\footnotetext{
* Author for correspondence
} 
globulins are expressed by a multigene family giving rise to trimer molecules that are highly heterogeneous (Sales et al., 2000). Results from our laboratory have shown that the resistance is associated with vicilin polypeptides which are expressed mostly in the cotyledons of the resistant seeds and that the association of vicilins to chitin, which is why these proteins are detrimental to insects, is dependent on tryptophan residues in the molecule (Miranda et al., 1998). Here we report the isolation of toxic polypeptides from vicilins that could be utilized for the identification of the domain(s) involved in the association with chitin and with the resistance to the bruchid.

\section{MATERIALS AND METHODS}

\section{Insects}

The cowpea weevil (Callosobruchus maculatus) colony utilized in this work was provided by Dr. J. H. Ribeiro dos Santos from the Centro de Ciências Agrárias, Universidade Federal do Ceará, Brazil and maintained in culture $\left(28{ }^{\circ} \mathrm{C}\right.$ and $70 \%$ $\mathrm{RH})$ at the Departamento de Bioquímica e Biologia Molecular, Universidade Federal do Ceará, Fortaleza, Ceará, Brazil.

\section{Seeds}

Cowpea (Vigna unguiculata) seeds of the line IT81D-1045, which were resistant (R) to the bruchid insect $C$. maculatus (Xavier-Filho et al. 1989), were obtained from IITA, Ibadan, Nigeria through the Centro Nacional de Pesquisa ArrozFeijão (CNPF/EMBRAPA), Goiânia, Goiás, Brazil. Cowpea seeds of the local cultivar CE-31, which were susceptible (S) to the same insect, were supplied by the Centro de Ciências Agrárias, Universidade Federal do Ceará, Fortaleza, Brazil where they were developed.

\section{Preparation of proteins}

Finely ground cowpea seed meal (1:10 meal to buffer ratio) was extracted with $50 \mathrm{mM}$ borate buffer, $\mathrm{pH} 8.0$ for $30 \mathrm{~min}$ at room temperature. After centrifugation for $30 \mathrm{~min}$ at $8,000 \mathrm{~g}$ and 4 ${ }^{\circ} \mathrm{C}$ the proteins in the supernatant were fractionated into albumins (water soluble proteins) and globulins (salt soluble proteins), which were obtained after dialysis against water and freeze drying. Vicilin type proteins from $V$. unguiculata were prepared following the protocol developed by Sammour et al. (1984) with some modifications (Macedo et al. 1993; Macedo et al. 1995). The borate buffer $(\mathrm{pH}$ 8.0) supernatant obtained as above was fractionated by ammonium sulfate precipitation and the 70 to $90 \%$ fraction was dialyzed against water and freeze dried. The vicilins from cowpea seeds were further purified by chromatography on a Sephacryl S-200 column $(3 \times 40 \mathrm{~cm})$ equilibrated and eluted with the same buffer used for extraction. The vicilin-rich fractions were recovered and submitted to an ionexchange chromatography step on a DEAESepharose column $(2 \times 12 \mathrm{~cm})$ equilibrated with $50 \mathrm{mM}$ Tris- $\mathrm{HCl}, \mathrm{pH} 8.0$ and eluted with a $\mathrm{NaCl}$ gradient $(0$ to $1 \mathrm{M})$ in the same buffer. Vicilin rich fractions were recovered and submitted to chromatography on a Sephacryl S-400 column (2.5 $\times 60 \mathrm{~cm}$ ) in $100 \mathrm{mM}$ Tris- $\mathrm{HCl}, 0.25 \mathrm{M} \mathrm{NaCl}, \mathrm{pH}$ 8.0. Vicilins were recovered by dialysis and freeze-drying. The degree of purification of the vicilins obtained by the above procedure was ascertained during the purification step itself since only the most quantitatively significant and symmetrical protein peaks were collected. SDSpolyacrylamide gel electrophoresis of the purified vicilins showed patterns similar to those obtained previously by us and by others (Sammour et al. 1984; Casey et al. 1986; Macedo et al. 1995).

Vicilin denaturation / DEAE-cellulose chromatography of vicilins under denaturing conditions. Purified vicilins (as above) were solubilized $(1 \mathrm{mg} / \mathrm{ml}$ to $16.7 \mathrm{mg} / \mathrm{ml})$ in phosphate buffer $(10 \mathrm{mM}, \mathrm{pH} 7.6)$ containing re-crystallized urea $(2 \mathrm{M}, 4 \mathrm{M}$, or $8 \mathrm{M})$ or guanidium hydrochloride ( $2 \mathrm{M}, 4 \mathrm{M}, 6 \mathrm{M}$ ) and left for $16 \mathrm{~h}$ at room temperature. After this time the solutions were dialyzed against water and utilized for SDSPAGE or DEAE-celulose chromatography in the presence of $8 \mathrm{M}$ urea. In this case a column $(2.2 \mathrm{x}$ $11.0 \mathrm{~cm}$ ) was prepared with the ion-exchanger in phosphate buffer (10 mM, pH 7.6) containing $8 \mathrm{M}$ urea. Chromatography was developed first in this last buffer and then with a $\mathrm{NaCl}$ gradient ( 0 to 0.5 $\mathrm{M})$ in the same buffer. The absorbance of the fractions $(2.2 \mathrm{ml})$ was read at $280 \mathrm{~nm}$ and those corresponding to peaks were pooled, exhaustively dialyzed against water and freeze-dried. The recovered fractions were utilized for SDS-PAGE and Western blotting and for feeding trials with $C$. maculatus. 


\section{SDS-PAGE}

Polyacrylamide gel electrophoresis of proteins was performed by the denaturing method of Laemmli (20). We utilized a $7.5 \%$ gel (acrylamide: bis acrylamide, 30:0.8) in glass plates $(10 \times 13.5 \times$ $0.45 \mathrm{~cm})$. Stacking gel was $5 \%$ acrylamide. Protein samples of $1 \mathrm{mg} / \mathrm{ml}$ were utilized and after electrophoresis for $3 \mathrm{~h}$ at $15 \mathrm{~mA}$ the gels were stained (Weber and Osborn, 1969) with Coomassie Brilliant Blue R 250 and de-stained with acetic acid/methanol. Proteins utilized as molecular mass standards for PAGE-SDS were bovine serum albumin (66 $\mathrm{kDa})$, ovalbumin (45 kDa), glyceraldehyde-3-phosphate dehydrogenase (36 $\mathrm{kDa})$, carbonic anhydrase $(29 \mathrm{kDa})$, soybean trypsin (Kunitz) inhibitor $(21.5 \mathrm{kDa})$, and lysozyme (14 kDa).

\section{Western blotting}

Immunodetection of proteins after SDS-PAGE and electrotransfer to nitrocellulose membranes was essentially done as suggested by Towbin et al. (1979). Antiserum against the purified vicilins (from CE-31 seeds) was prepared by immunization of white rabbits. Purified antiserum was obtained by affinity chromatography of the crude immune sera on a column of Protein A covalently bound to Sepharose CL-4B. Preimmune sera were collected before immunization.

\section{Feeding Trials}

To test for the potential deleterious effects of vicilins and of the various isolated fractions on $C$. maculatus development, we employed an artificial seed system previously developed in our laboratory (Macedo et al 1993). Artificial seeds (400 mg) were made of finely ground cowpea (CE-31) seed meal containing the several vicilin preparations at $2 \%$ final concentration. The infestation of the artificial seeds was accomplished by placing 2-day-old female cowpea weevils in glass vials containing three seeds for 24 hours at $28{ }^{0} \mathrm{C}, 70 \% \mathrm{RH}$. The excess eggs laid were removed from the seeds leaving 4 eggs per seed. After 20 days infested seeds were opened and the weight and number of larvae were counted. Control artificial seeds were made with the meal of cowpea seeds (CE-31) without additions. All the experiments were run in triplicate and the data were analyzed by Tukey's test.

\section{RESULTS AND DISCUSSION}

Vicilins from CE-31 (S) and IT81D-1045 (R) seeds were prepared by a method originally developed by Sammour et al. (1984) which employed gel filtration and ion exchange chromatographies.
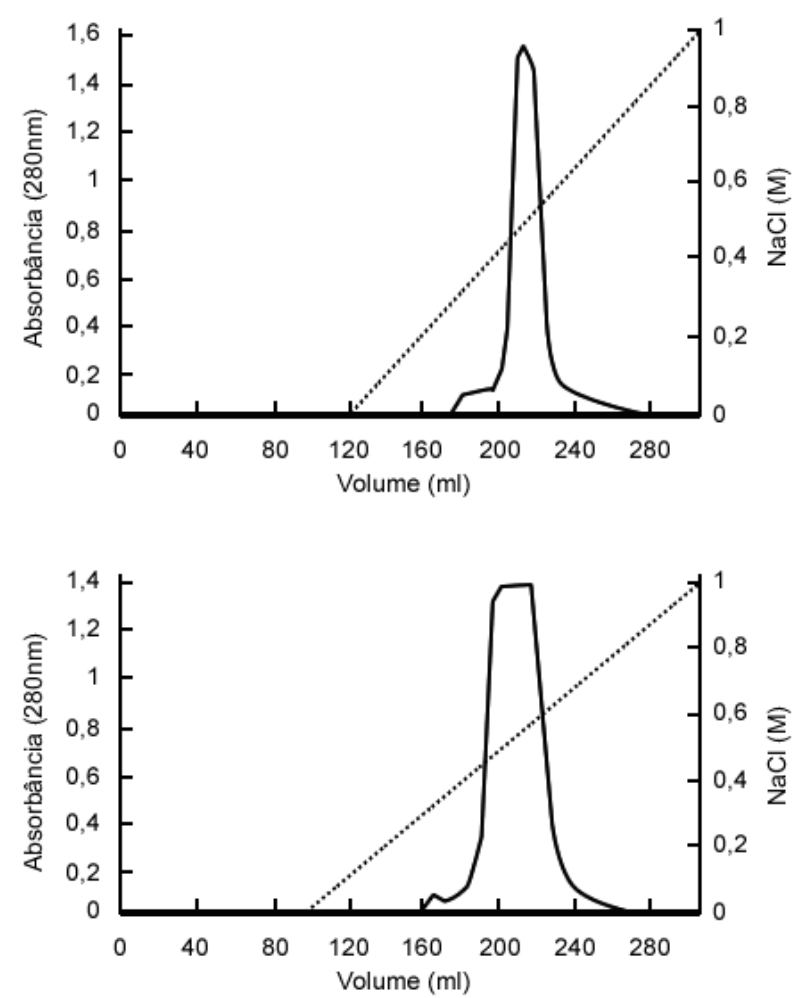

Figure 1 - DEAE-Celulose chromatography of vicilins obtained by gel filtration (in Sephacryl S-400). Upper panel, vicilin from CE-31 seeds; lower panel vicilins from IT81D-1045 seeds.

In the Sephacryl S-400 gel filtration step a major peak of protein was obtained. The protein contained in this peak was chromatographed in DEAE-celulose when we obtained a single peak that was desorbed by a gradient of $\mathrm{NaCl}$ (Fig. 1). Analysis of the proteins in these peaks by SDSPAGE showed typical profiles for the vicilins studied (not shown). 

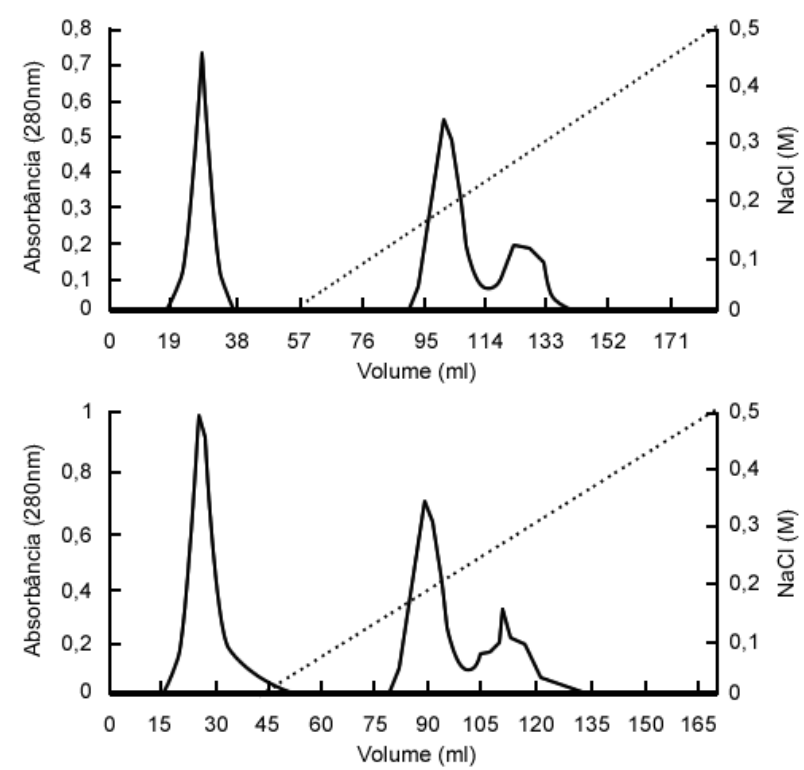

Figure 2 - DEAE-Celulose chromatography in $8 \mathrm{M}$ urea. Denatured vicilins from CE-31 (upper panel) and IT81D-1045 (lower panel) seeds. Fractions UD-I, UDII and UD-III from left to right.

Purified vicilins were denatured by urea $(2,4$, and $8 \mathrm{M}$ ), which did not cause any modifications in mobilities as seen by SDS-PAGE (not shown).

When urea treated vicilins were submitted to ion exchange chromatography in DEAE-celulose in the presence of the denaturant three fraction profiles were obtained (Fig. 2). This finding suggested that urea-denaturation produced polypeptides with different total charges. The different fractions were recovered and analyzed by SDS-PAGE. The fractions from both vicilins (CE31 and IT81D-1045) were found to be formed by multi-sized polypeptides (not shown). The majority of these polypeptides were shown to be immunologically related to vicilins.

Fractions isolated from urea denatured vicilins were tested for toxicity to $C$. maculatus in artificial seeds and shown to affect differently survival and development of the bruchid. Denaturation and renaturation of vicilins from both susceptible and resistant seeds did not, apparently, alter their effects on C. maculatus (Table 1). Control seeds containing $1 \%$ urea $(170 \mathrm{mM})$ did not affect larval survival or development. The effects of the several fractions isolated from ion-exchange chromatography experiments in the presence of $8 \mathrm{M}$ urea on C. maculatus suggest that the most acidic polypeptides, those retained by the ion-exchanger and desorbed by the sodium chloride gradient (Fig. 2), were detrimental to the bruchid, especially the fraction originated from IT81D-1045 vicilin (R), which did not permit development of the insect at $2 \%$ concentration (Table 1 ).

Table 1 - Behavior of Callosobruchus maculatus on artificial seeds containing vicilins isolated from CE-31 (S) and IT81D-1045 (R) cowpea seeds and fractions originated from ion-exchange chromatography separations of the ureadenatured proteins.

\begin{tabular}{l|c|c|c|c}
\hline \multicolumn{2}{c|}{ CE-31 } & \multicolumn{2}{c}{ IT81D-1045 } \\
\hline & Number of larvae & $\begin{array}{c}\text { Mass of one larva, } \\
\text { mg }\end{array}$ & Number of larvae & Mass of one larva, mg \\
\hline Seed meal & $2.89 \pm 0.19^{\mathrm{a}}$ & $9.60 \pm 0.33^{\mathrm{a}}$ & $2.33 \pm 0.00^{\mathrm{a}}$ & $3.72 \pm 0.09^{\mathrm{c}}$ \\
Vicilin & $3.22 \pm 0.51^{\mathrm{a}}$ & $8.71 \pm 0.47^{\mathrm{a}}$ & $2.67 \pm 0.33^{\mathrm{a}}$ & $5.71 \pm 0.28^{\mathrm{b}}$ \\
Vicilin, urea denatured & $2.67 \pm 0.58^{\mathrm{a}}$ & $7.61 \pm 0.71^{\mathrm{b}}$ & $2.33 \pm 0.58^{\mathrm{a}}$ & $5.40 \pm 0.47^{\mathrm{b}}$ \\
UD-I & $2.44 \pm 0.51^{\mathrm{a}}$ & $6.55 \pm 0.54^{\mathrm{b}}$ & $2.33 \pm 0.58^{\mathrm{a}}$ & $5.97 \pm 0.82^{\mathrm{b}}$ \\
UD-II & $3.11 \pm 0.19^{\mathrm{a}}$ & $5.88 \pm 0.79^{\mathrm{c}}$ & $2.11 \pm 0.19^{\mathrm{a}}$ & $6.15 \pm 1.14^{\mathrm{a}}$ \\
UD-III & $2.00 \pm 0.00^{\mathrm{b}}$ & $0.76 \pm 0.15^{\mathrm{d}}$ & $0.00 \pm 0.00^{\mathrm{b}}$ & $0.00 \pm 0.00^{\mathrm{d}}$ \\
$1 \%$ Urea & $2.44 \pm 0.19^{\mathrm{a}}$ & $8.01 \pm 0.51^{\mathrm{a}}$ & $2.89 \pm 0.51^{\mathrm{a}}$ & $7.63 \pm 0.30^{\mathrm{a}}$ \\
\hline
\end{tabular}

All experiments were run in triplicate. Means followed by the same letter in a column are not statistically different at the level of 5\% (Tukey's test).

We also observed that the corresponding fraction from CE-31 vicilin (S) was also detrimental but not at the same level (Table 1). As we did not see any strong effect due to urea treatment on the other fractions we speculated that the toxicity of the UD-III fraction from CE-31 vicilin could be due to polypeptides present in the preparation which were similar to the ones present in fraction UD-III from
IT81D-1045 vicilin (R). This finding could indicate that genes for $C$. maculatus-resistant vicilin polypeptides might be also present in susceptible vicilins but were expressed at low levels that permited development and survival of the insect. 


\section{RESUMO}

Vicilinas (globulinas de reserva 7S) isoladas de sementes de feijão-de-corda (Vigna unguiculata L.), susceptíveis (S) e resistentes (R) ao caruncho/gorgulho (Callosobruchus maculatus F., Coleoptera: Bruchidae) foram desnaturadas por uréia e fracionadas por cromatografia de troca iônica. As frações isoladas foram incorporadas em sementes artificiais para avaliação de sua toxicidade a $C$. maculatus. As fracões mais ácidas de ambas vicilinas afetaram o desenvolvimento e a sobrevivência do bruquídeo. Sugerimos que polipeptídeos de vicilinas de natureza tóxica são expressos em ambos tipos de globulinas de reserva, embora em níveis diferentes.

\section{REFERENCES}

Casey, R.; Domoney, C. and Ellis, N. (1986), Legume storage proteins and their genes. In: B. J. Miflin ed., Oxford Surveys of Plant Molecular Biology and Cell Biology. Oxford University Press, Oxford, 1 - v.3, 95p.

Egwuatu, R. I. (1987), Current status of conventional insecticides in the management of stored product insects in the tropics. Insect Sci. Applic. 8, 695-701.

Jackai, L. E. N. and Daoust, R. (1986), Insect pests of cowpeas. Annu. Rev. Entomol. 31, 95-119.

Macedo, M. L. R.; Andrade, L. B. S.; Moraes, R. A. and Xavier-Filho. J. (1993), Vicilin variants and the resistance of cowpea (Vigna unguiculata) seeds to the cowpea weevil (Callosobruchus maculatus), Comp. Biochem. Physiol. 105C, 89-94.

Macedo, M. R. L.; Fernandes, K. V. S.; Sales, M., P. and Xavier-Filho, J. (1995), Purification and properties of storage proteins (vicilins) from cowpea (Vigna unguiculata) seeds which are susceptible or resistant to the bruchid beetle Callosobruchus maculatus. Braz. J. Med. Biol. Res. 28, 183-190.
Miranda, M. R. A.; Oliveira, A. E. A.; Fernandes, K. V. S. and Xavier-Filho, J. (1998), Chemical modifications of vicilins from Vigna unguiculata seeds. XXVII Meeting of the Brazilian Biochemistry and Molecular Biology Society, Caxambu (MG) Brazil. Abstract Book, p34.

Sales, M. P.; Gerhardt, I. R.; Grossi-de-Sá, M. F. and Xavier-Filho, J. (2000), Do Legume Storage Proteins Play a Role in Defending Seeds Against Bruchid Larvae?. Plant Physiol., 124, 515-522.

Sammour, R. H.; Gatehouse, J. A.; Gilroy, J. and Boulter, D. (1984), The homology of the major storage protein of jack bean (Canavalia ensiformis) to pea vicilin and its separation from $\alpha$-manosidase. Planta 161, 61-70.

Singh, B. B. and Singh, S. R. (1992), Breeding for bruchid resistance in cowpea. IITA Res. 5, 1-5.

Singh, S. R. and Rachie, K. O. (1985), Cowpea Research, Production and Utilization, WileyInterscience, Chichester, 460.

Towbin H.; Stachelin N. T. and Gordon J. (1979), Electrophoretic transfer of proteins from polyacrylamide gels to nitrocellulose sheets; procedures and some applications. Proc. Natl. Acad. Sci., 176, 4350-4354.

Weber, K. and Osborn, M. (1969), The reliability of molecular weight determinations by dodecyl sulfatepolyacrylamide gel electrophoresis. J. Biol. Chem., 244, 4406-4412.

Xavier-Filho, J.; Campos, F. A. P.; Ary, M. B.; Silva, C. P.; Carvalho, M. M. M.; Macedo, M. L. R.; Lemos, F. J. A. and Grant, G. (1989), Poor correlation between the levels of proteinase inhibitors found in seeds of different cultivars of cowpea (Vigna unguiculata) and the resistance/susceptibility to predation by Callosobruchus maculatus. J. Agric. Food Chem., 37, 1139-1143.

Received: December 12, 2000; Revised: March 19, 2001; Acepted: June 11, 2001. 